\title{
İkinci Karabağ Savaşı Sonrası Azerbaycan - Türkiye İlişsileri
}

\author{
After Second Karabakh War Azerbaijan - Turkey Relations
}

\section{Murteza HASANOĞLU}

Doç. Dr., Azerbaycan Devlet Idarecilik Akademisi, m_hasanoglu@yahoo.com.tr https://orcid.org/0000-0003-3734-4045

\section{Asim MEMMEDOV}

Doç. Dr., Gence Devlet Üniversitesi,

Tarih - Coğrafya Fakültesi, Sosyal Bilimler Bölümü, asim_gdu@yahoo.com https://orcid.org/0000-0001-9517-5214

\section{Bahtiyar MAHARRAMOV}

Ögrr. Gör., Gence Devlet Üniversitesi, Tarih - Coğrafya Fakültesi, Genel Tarih Bölümü, mbaxtiyar74@gmail.com https://orcid.org/0000-0001-8446-1063
Makale Başvuru Tarihi: 13.12.2020

Makale Kabul Tarihi: 26.12.2020

Makale Türü: Araştırma Makalesi

\section{ÖZET}

Anahtar
Kelimeler:
Türkiye,
Azerbaycan,
Dağlık Karabă̆
Savaşı,
Güney Kafkasya,
Stratejik Ortaklık,

Keywords:

Turkey,

Azerbaijan,

Nagorno-Karabakh War,

South Caucasus,

Strategic Partnership,
1991 yılında bağımsızlığına kavuşan Azerbaycan Cumhuriyeti nin en büyük destekçisi, Türkiye Cumhuriyeti olmuştur. Türkiye, Azerbaycan `n bağımsızlı̆̆ını ilk tanıyan devlettir. Bağımsızlı̆̆ını kazandı̆̆ ilk günden itibaren Ermenistan `̀n işgalci siyaseti sonucunda Azerbaycan, Dağllk Karabağ ` ve yedi rayonu kaybetmiştir. Pek çok BM Güvenlik Konseyi kararı Ermenistan ın işgal ettiği topraklardan çekilmesi gerektiğini karara bağlamış, ancak Ermenistan işgalini sürdürmüştür. 27 Eylülde başlattığı karşı saldırı sonucunda topraklarını işgalden kurtarmayı başarmıştır. 10 Kasım 2020`de imzalanan bildiri ile Ermenistan savaşı kaybeden taraf olarak Azerbaycan ın koşullarını kabul etmek zorunda kalmış ve işgal ettiği topraklarından askeri gücünü çekmeyi kabul etmiştir. Türkiye bu savaşta Azerbaycan`ı askeri, siyasi ve diplomatik açıdan destekleyen en önemli devlet olmuştur. Savaș öncesi iki devlet arasında ilişkiler hem ekonomik, hem siyasi açıdan stratejik ortaklık düzeyine uaşmıştır. İki devletin girişimi ile çok sayıda ortak ekonomik proje gerçekleşmiştir. Askeri alanda da taraflar arasında imzalanan anlaşmalar Azerbaycan `̀n savașta zafere ulașmasında önemli etken olmuştur. İkinci Karabă̆ savaşından Azerbaycan `̀n zaferle ayrılması Güney Kafkasya 'da kalıcı barışın tesis edilmesi için çok önemlidir. Bu durum Türkiye açısından da yeni firsatlar doğuracak, Güney Kafkasya'da konumunu güçlendirecektir. Özellikle Nahçivan ile Azerbaycan arasında koridorun açılması Türkiye yi doğrudan Azerbaycan ve Hazar Denizi üzerinden Orta Asya ya birleştirecektir. Bunun sonucunda Türkiye siyasi, ekonomik ve askerî açıdan daha etkin aktöre dönüşecektir.

\section{ABSTRACT}

Since the independence of the Republic of Azerbaijan in 1991, the major country showing solidarity with Azerbaijan has been the Republic of Turkey. Turkey is the first country to recognize Azerbaijan's independence. Since the first days of its independence, Azerbaijan had lost Nagorno-Karabakh and seven adjacent districtsas a result of the invasion policy of Armenia. Numerous United Nations Security Council decisions concluded that Armenia should withdraw from the occupied territories, but the Armenian occupation continued. However, Azerbaijan succeeded in liberating its lands from the occupation as a result of a counter-attack it launched on September 27. With the declaration signed on 10 November 2020, Armenia, as the loser of the war, had to accept the conditions of Azerbaijan and agreed to withdraw its military power from the territories it had occupied. During this war, Turkey has been the most important country supporting Azerbaijan in military, political and diplomatic terms. Before the war, relations between two states reached the level of strategic partnership both economically and politically. Many joint economic projects have been realized with the initiative of the two states. The agreements signed between the parties in the military field have also been an important factor in Azerbaijan's victory in the war. The victory of Azerbaijan from this second Karabakh war is very important for the establishment of permanent peace in the South Caucasus. This will bring new opportunities in terms of Turkey as well, and it will strengthen its position in the South Caucasus. In particular, the opening of the corridor between Azerbaijan and Nakhchivan will connect Turkey through Azerbaijan and the Caspian Sea directly to the Central Asia. As a result, Turkey will become a more effective actor politically, militarily and economically. 


\section{GIRISS}

Uzun bir süredir aralarında sorunlar bulunan Azerbaycan ve Ermanistan devletleri arasındaki gerginlik 2020 Eylül ayı itibari ile yeni bir boyut kazanmıştır. 27 Eylül 2020 sabahı Azerbaycan ordusu defalarca ateşkesi ihlal eden Ermenistan ordusuna karşı işgal altındaki topraklarını kurtarmak için karşı taarruza başlamıştır. Ermenistan bu savaşta Rusya ve Fransa gibi büyük güçlerin her türlü desteğine rağmen, Azerbaycan ordusunun hücumlarına sadece 44 gün dayanabilmiştir. 44 gün zarfında Azerbaycan`ın hızlı ve askeri açıdan çok düzgün kurgulanmış hücumları, Ermenistan'ın işgal altında tuttuğu rayonlardan, büyük kayıplar vererek düzensiz bir şekilde geri çekilmesine neden olmuştur. 10 Kasım gününün ilk saatlerinde Ermenistan`ın teslim olması anlamına gelen ve Azerbaycan`ın taleplerinin yer aldığı ateşkes bildirisinin imzalanması ile Dağlık Karabağ a komşu olan ve Ermenistan işğalindeki yedi rayon (il) kayıtsız şartsız tam olarak Ermeni askerlerinden ve bu rayonlara Azerbaycan`ın izni olmadan yerleştirilmiş sivillerden arındırılmıştır. Ayrıca Azerbaycan için büyük öneme sahip Şuşa şehri başta olmakla Dağlık Karabağ bölgesinin bazı yerleşim alanları Azerbaycan`ın kontrolüne geçmiş ve Ermeni unsurlardan arındırılmıştır. İmzalanan “Üçlü Bildiri”ye göre Dağlık Karabağ’ın geri kalan kısmında bulunan Ermenistan askerleri bölgeyi terk edecek ve bölge silahlı unsurlardan tamamen arındırılması noktasında mutabık kalınmıştır. Bu sürecin işleyişinde Rus barış gücü önemli görevler üstlenecek, barış sürecinin denetiminde ise Türk-Rus ortak askeri komuta merkezi görev alacaktır.

Barış antlaşması Azerbaycan açısından sadece askeri alanda kazandığı bir başarı olarak tarihe geçmemiştir. Bu büyük zaferde Azerbaycan diplomasisinin uzun süreli ve bilinçli çalışmalarının da payı bulunmaktadır. 30 yıldan fazladır devam eden çalışmalar sayesinde Azerbaycan kendi tezini tüm dünyaya duyurmayı başarmış, çok sayıda devletin desteğini kazanmış ve uluslararası örgütlerde Ermenistan`ın işgalci devlet olarak tanınmasını sağlamıştır. Bu diplomatik girişimler sonucunda da Azerbaycan giderek Dağlık Karabağ sorununun adil bir biçimde çözüme kavuşmasının yasal ve siyasi temelini oluşturmuştur. Buna karşılık Ermenistan savaştan sadece askeri açıdan değil, hem siyasi açıdan, hem diplomatik açıdan, hem de dünya kamuoyunu etkileyebilme gücü açısından savaştan yenik çıkmıştır. Azerbaycan, egemenliği altında olmasına rağmen işgal edilmiş olan topraklarını kurtarmak için her türlü diplomatik, hukuki ve politik temeli tesis etmişken ve de sahada Ermenistan ordusuna karşı mutlak bir üstünlük sağlamıken, Rusya ’nın ateşkes isteğine ve sorunun bundan sonraki kısmının diplomatik yolla çölümlenmesi talebine olumlu karşılık vermiştir. Bu durum Azerbaycan`ın barış yanlısı bir devlet olduğu imajını daha da güçlendirmiştir.

Azerbaycan kendi topraklarını işgalden kurtarmak için yeteri kadar askeri güce sahip olduğunu, ancak bölgedeki sorunun çözümü için barış sürecine öncelik verdiğini tüm dünyaya kanıtlamıştır. Savaş esnasında kendi sivil halkına yönelik sürekli ve doğrudan bir saldırı olması ve bu yönde tahrik edilmesine rağmen, hiçbir şekilde sivilleri hedef almamış, orantısız güç kullanmamıştır. Kontrollü ve barış odaklı bir süreç yönetimi gerçekleştirmiştir. Azerbaycan`ın bu tutumu bölgenin geleceği açısından önemli bir adımdır. Dağlık Karabağ sorunu kapsamında Azerbaycan`ın attığ çözüme yönelik adımlar, bölgede Ermenistan`ın da katılacağ çok taraflı yeni işbirliği ortamının temelinin atılmasına katkı sağlamıştır. Çünkü bölgede kalıcı bir barış ve işbirliği sürecinin gerçekleşmesi, bölge ülkelerinin toprak bütünlügünün sağlanması ve onların birbirlerinin egemenlik hukukuna saygı göstermesi çerçevesinde söz konusu olabilecektir. Bu gerçekliği en iyi gören ve anlayan ülkeler ise Türkiye ve Azerbaycan'dır.

$\mathrm{Bu}$ çalışma İkinci Karabağ Savaşı olarak isimlendirilen sürecin öncesi ve sonrasındaki Türkiye-Azerbaycan ilişkilerinin geldiği boyutu merkeze almaktadır. Bu çerçevede, yaşanan savaş neticesinde bölgede oluşacak yeni huhuki, siyasi ve fiziki atmosferde Türkiye ve Azerbaycan'ın ortak hareket etmesinin etkilerinin neler olabileceği ele alınmıştır. Bununla birlikte, konunun genel değerlendirmesi yapılarak, iki ülke ilişkilerinin uluslararası etkileri hakkında bir gelecek projeksiyonu çıkartılmıştır.

\section{2. İKINNCI KARABAĞ SAVAŞI ÖNCESİ TÜRKIYE - AZERBAYCAN İLISSTILERİ}

Birinci Karabağ Savaşı 1994 yılında Bişkek’te imzalanan ateşkes anlaşması ise sona ermiştir. Ancak aradan geçen 26 yıllık sürede Ermenistan tarafının uzlaşmaz tutumu nedeniyle taraflar arasında kalıcı bir barış sağlanamamıştır. Yaşanan bu süreç, her iki ülkeyi de ekonomik açidan olumsuz etkilemiştir. Azerbaycan ekonomisi egemenliğini kazanmasının ardından Birinci Karabağ Savaşı sonrasında ciddi sıkıntılarla karşı karşıya kalmıştır. Üretimin azalması, ithalatın artması, ülke dışından gelen mülteciler ve ülke içinde yaşanan darbe teşebbüsü ile oluşan iktidar değişimi de bu dönemde ekonomiyi olumsuz yönde etkilemiştir (Çeliksoy, 2020:64-65). 
Birinci Karabağ Savaşı sonrasında her ne kadar Azerbaycan toprakları işgal altında olsa da yaşanan gelişmeler orta ve uzun vadede Azerbaycan'ın lehine gerçekleşmiştir. Azerbaycan, sahip olduğu yer altı zenginlikleri ve stratejik potansiyelini rasyonel bir şekilde kullanarak ekonomik açıdan güçlenmeye ve iktisadi kalkınmaya önem vermiştir. Haydar Aliyev'in tesis ettiği gelişmeci ve kalkınmacı siyaset politikası ile küresel devletler ile olan ilişkiler ülke bağımsızlığı esas alınarak geliştirilmiştir. Küresel devletlerin de katılımı ile büyük ölçekli ekonomik projelerin temeli atılmıştır. 2000 li yıllardan itibaren bu projeler birer birer hayata geçirilmeye başlanmıştır. Söz konusu uluslararası projelerin gerçekleşmesi sonucunda ekonomik açıdan daha güçlü ve bağımsız hareket edebilme kabiliyetine sahip olmuştur. Ermeni diasporasından ve Rusya'dan gelen hibelerle ayakta kalmaya çalışan işgalci Ermenistan`ı geride bırakmış ve topraklarını işgalden kurtaracak duruma gelmiştir.

Orta Asya Türk Devletleri arasında en eski devlet kültürüne ve hali hazırda en iyi ekonomiye sahip olan Azerbaycan, birçok noktada bölge devletleri için rol model konumundadır (Mecek, 2018:51). Azerbaycan'ın ekonomik açıdan sahip olduğu olumlu gelişmenin temelinde iki ana unsur bulunmaktadır. Bunlardan birisi sahip olduğu tarihsel kökenidir. Diğeri ise yine ülkenin gelişme yanlısı liderlere sahip olmasıdır (Tan vd., 2013: 530). Bunun yanısıra bağımsızlık sonrasında demokratikleşme ve yerel katılım konusunda da önemli kazanımlar elde edilmiştir (Kocaoğlu, 2015:36). Dolayısıyla başta ekonomi ve kalkınma olmak üzere eğitim, savunma, demokrasi ve alt yapı çalışmalarının optimal bir şekilde hayata geçirilmesi ve bu konuda gerek komşu ülkeler ve gerekse küresel devletler ile işbirliği içinde bulunularak yeni dünya düzenine etkin bir şekilde ayak uydurulabilmesi Azerbaycan'ı başarıya taşımışı̧ı.

İşgal sürecinde Azerbaycan ile Türkiye arasında politik, diplomatik, askeri ve ekonomik alanlarda hızla genişleyen ve giderek yüksek stratejik düzeye ulaşan ilişkiler başlamıştırtır. 8 Şubat 1994`te Azerbaycan Cumhurbaşkanı Haydar Aliyev'in Türkiye`ye ilk resmi ziyareti gerçekleşmiştir. Üç gün devam eden ziyarette iki devlet arasında stratejik ortaklık düzeyine ulaşacak ilişkilerin temeli atılmıştır. Aynı yılın 20 Eylül ünde dünyanın enerji güvenliği ve Azerbaycan’ın bağımsızlığı ve gelişimi açısından büyük önem taşıyacak "Asrın Anlaşması"nda Türkiye Cumhuriyeti'ni temsilen “Türkiye Petrolleri Anonim Ortaklığı” şirketi de yer almıştır.

7-9 Aralık 1995 tarihlerinde Türkiye Cumhuriyeti Cumhurbaşkanı Süleyman Demirel Azerbaycan`a resmi bir ziyaret gerçekleştirmiştir. Ziyarette taraflar arasında ortak bildiri ve ekonomik işbirliği anlaşması imzalanmıştır. 1996 yılında ise taraflar arasında diplomatik, politik ve askeri alanda bazı önemli işbirliği anlaşmaları gerçekleştirilmiştir. Tüm bu gelişmeler Azerbaycan ile Türkiye arasındaki streteji ortaklığın temelini oluşturmuştur. $\mathrm{Bu}$ durum Türkiye’nin ekonomik, ticari ve siyasi açıdan sadece Azerbaycan`a değil, Güney Kafkasya ya girişini hızlandırmıştır. Azerbaycan ise bu ilişkiden büyük kazanımlar elde etmiştir. Gürcistan üzerinden Türkiye ye ve oradan ise tüm Avrupa'ya açılmıştır. Böylelikle Rusya 'nın ülke üzerindeki baskıları dengelenmiş ve coğrafi açıdan Rusya ya olan bağımlılıktan kurtulunmuştur. Rusya bağımlılığına alternatif olarak Türkiye ve Karadeniz üzerinden dünyaya açılmanın yollarına kavuşmuştur.

5 Mayıs 1997 tarihlerinde Azerbaycan ile Türkiye arasındaki stratejik işbirliğini derinleştirmekle ilgili yeni bir bildiri devreye girmiştir. Bu çerçevede küçük ve orta ölçekli sanayi müesseselerinin gelişimine dair protokol ile elektro-enerji alanında işbirliği anlaşması imzalanmıştır (Hasanov, 2005:469-470).

Eylül 1998`de “Avrupa-Kafkasya-Asya Transkafkasya Programı” çerçevesinde 32 devlet ve 13 uluslararası örgütün katılımı ile "Büyük İpek Yolu"nun yeniden kurulmasına dair gerçekleşen uluslararası konferans Türkiye - Azerbaycan ilişkilerinin daha da derinleşmesine katkı sağlamıştır (Ahmedov, 2020). İki ülke arasındaki ilişkiler son derece dinamik bir biçimde gelişmeye devam etmiş ve bu gelişimden bölge ülkesi olan Gürcistan da yararlanmıştır. Nitekim 1999'da İstanbul'da gerçekleşen AGİT Zirve toplantınsında üç ülkenin katılımı ile Azerbaycan petrollerinin uluslararası piyasalara naklini gerçekleştirecek ana nakil hattı hakkında Bakü-Tiflis-Ceyhan Ana Petrol Kemeri Anlaşması imzalanmıştır. Bu anlaşma ile Türkiye'nin Güney Kafkasya'daki pozisyonu daha da güçlenmiş ve bölgenin en önemli ekonomik ve politik aktörüne dönüşmüştür.

İlham Aliyev`in 2003 yılında Azerbaycan Cumhurbaşkanı olması ile Türkiye - Azerbaycan ilişkilerinin niteliği artmaya devam etmiştir. İki ülke arasındaki ilişkiler her alanda daha da derinleşmiş ve yine her iki ülke açısından da kazanımlar sağlayan praktik sonuçlar doğurmaya başlamıştır. 2004 yılı Nisanı nda İlham Aliyev`in Türkiye'ye ilk resmi ziyareti gerçekleşmiştir. Söz konusu ziyaret sırasında taraflar arasında önemli sonuçlar doğuracak yeni anlaşmalar imzalanmıştır. 2006 yılında ise Azerbaycan ve Türkiye ilişkileri açısından son derece önemli bir yıl olmuştur. Uzun ve yorucu diplomatik, siyasi ve ekonomik mücadele sonucunda yapımı tamamlanan Bakü-Tiflis-Ceyhan Petrol Boru Hattı 13 Temmuz 2006 da açılmıştır. Bakü'den yola çıkan ham petrol Ceyhan limanına doğru hareket etmiştir (Ahmedov, 2019). 
Hattın çalışmaya başlaması sadece Azerbeycan - Türkiye ilişkilerinin gelişimine değil, aynı zamanda Türkiye`nin Gürcistan ile ilişkilerinin gelişimine de katkı sağlamıştır. Ağustos 2008`de Rusyya'nın Gürcistan`a askeri müdahalede bulunmasınından sonra, askeri açıdan gelişini hızlandırmak isteyen Tiflis yönetimi, Türkiye ile askeri alanda da işbirliğini geliştirmeye karar vermiştir. 2000'li yılların başından itibaren Türkiye, Gürcistan`ın en önemli ekonomik ve ticari ortaklarından birisi haline dönüşmüsstür. Türkiye - Gürcistan ortaklığı aynı zamanda Gürcistan`ın hem Güney Kafkasya`da, hem de genel olarak Karadeniz bölgesinde önemli ekonomik projelerde yer almasına olanak sağlamıştır (Sam, 2011:32). 2006 yılında Rusya, Gürcistan`ın ihraç ürünlerine ambargo uygulamıştır. Türkiye'de bu bağlamda Gürcistan`da Serbest Ticaret Anlaşması imzalamış ve pazarlarını Gürcü mallarına açmıştır.

2007 yılında Türkiye ile Azerbaycan arasında Bakü-Tiflis-Erzurum Doğalgaz Hattının yapılması ile bağlı proje nihayet tamamlanmış ve $980 \mathrm{~km}$ uzunluğunda doğalgaz hattı faaliyete başlamıştır. Bu hat ile Şahdeniz yatağından çıkarılan Azerbaycan doğal gazı Türkiye ye taşınmaya başlamıştır.

Temmuz 2008 döneminde Azerbaycan Cumhurbaşkanı Aliyev, Türkiye`ye ziyarete gelmiştir. Ziyaret kapsamında Kars şehrinde Bakü-Tiflis-Kars Demiryolu hattının Türkiye kısmının temel atma töreni düzenlenmiştir. Aliyev tören konuşmasında, Azerbaycan'ın uluslararası enerji ve taşımacılık koridoru olarak büyük imkânlara sahip olduğunu belirterek, temeli atılan demir yolu ile bunun çok daha artacağını ifade etmiştir. Ayrıca bu projenin bölgesel işbirliğinin geliştirilmesi için çok önemli bir role sahip olduğunu söylemiştir.

BTC, BTE ve BTK hatları bugün bölgenin en büyük ve en önemli projeleri arasındadır. Her üç projenin de Bakü'den başlaması, sadece Azerbaycan’ın petrol ve doğalgaz rezervlerine sahip olması ile ilgili değildir. Azerbaycan'ın bölgede en büyük ekonomik poransiyele ve güce sahip olması dolayısı ile söz konusu projelerin güzergâhını belirleme konusunda söz hakkına sahip olması ile de ilgilidir. Aliyev konuşmasında Azerbaycan Türkiye ilişkilerinin gelecek perspektiflerine de değinerek bu işbiriğinin Kafkasya jeopolitiğindeki özel önemini belirtmiştir.

Türkiye - Azerbaycan ilişkileri 2000'li yılların başlarından itibaren ekonomi dışındaki diğer alanlara da yayılmıştır. Özellikle askeri alanda daha derin işbirliği yapma olanakları üzerinde çalışmalar yapılmıştır. Bu kapsamda iki ülke arasında askeri - politik işbirliğinin ve Türkiye’nin Azerbaycan`1 dış tehditlere karşı yalnız bırakmayacağının en önemli sinyali 2001 yılında verilmiştir. 2001 yılında Türkiye’nin İran uçaklarının Azerbaycan sınırlarını ihlal ederek tacizde bulunmasına karşı, İran`a itiraz notası göndermiştir. En önemlisi ise aynı yılın Ağustos ayında Türk uçakları Bakü’ de hava gösterisi düzenlemiştir. Türkiye Cumhuriyeti Genel Kurmay Başkanı Orgenerel Hüseyin Kıvrıkoğlu Azerbaycan`1 ziyaret ederek İran`a gereken mesaj verilmiştir (Sam, 2011:35). Bu olay, Türkiye - Azerbaycan ilişkilerinin gelişimine paralel olarak Türkiye`nin Güney Kafkasya'da giderek önemli siyasi aktöre dönüştüğünü göstermektedir.

Türkiye - Azerbaycan ilişkileri 2010 yılından itibaren daha da güclü bir aşamaya geçmiştir. 16 Ağustos`ta Türkiye Cumhurbaşkanı Abdullah Gül ’ün Azerbaycan’a resmi ziyareti sırasında imzalanan "Stratejik Ortaklık ve Karşı1ıklı Yardım Anlaşması" ve 15 Eylül’de Yüksek Düzeyli Stratelik İşbirliği Konseyi’nin oluşturulması ile iki devlet arasındaki işbirliğinin bağı kuvvetlenmiştir. Bu anlaşma ve oluşturulan konsey, her iki devlet açısından da dış ilişkilerindeki en yüksek düzeyli işbirliği modelidir (Aslanlı, 2020). Böylece Azerbaycan'ın dış politikasında Türkiye ile ilişkileri özel bir önem taşımaya başlamışıı. Anlaşmanın birinci maddesinde açık bir biçimde tarafların birinin toprak bütünlüğüne ve dokunulmazlığına karşı bir tehtid ortaya çıktığında ya da bu yönde bir tehlike ile karşılaşıldığında veya bu yönde bir öngörü oluştuğunda tarafların acilen istişareler yapacağ 1 hüküm altına alınmıştır. İkinci maddesine göre ise, taraflardan biri, üçüncü devlet veya birkaç devlet tarafından silahlı baskın veya askeri tecavüze maruz kalırsa, BM Tüzüğünün 51. maddesi uyarınca, toplu savunma önlemlerinin alınması hakkı kapsamında birbirlerine yardımda bulunacaklardır (Strateji Ortaklık ve Karşılıklı Yardım Anlaşması, md.2). Bu anlaşma ve oluşturulan Yüksek Düzeyli Stratelik İşbirliği Konseyi iki ülke arasında askeri ittifakın oluşturulması açısından en önemli yasal dayanağı oluşturmaktadır. Söz konusu Konsey’in yasal dayanağını oluşturan anlaşmanın imza töreninde konuşan Azerbaycan Cumhurbaşkanı Aliyev, "bugün imzalanan belge, aslında bugüne kadar görülen işlerin bir anlamda devamı niteliğindedir, stratejik ortakliğımızın gelecek gelişimini belirlemektedir”, demiştir (Azerbaycan Cumhurbaşkanlığı, 2011).

2011 yılının Temmuz ayında Türkiye Cumhuriyeti Cumhurbaşkanı (o zaman Başbakan) Recep Tayyip Erdoğan Azerbaycan'ı ziyaret etmiştir. Ziyaret kapsamında Azerbaycan Cumhuriyeti Cumhurbaşkanı İlham Aliyev iki ülke arasındaki ilişkilerin geliştirilmesi ile ilgili olarak, "Bizi birleştiren unsurlar; hem tarihi köklerimiz, hem kültürel ilişkilerimiz, geçmişimiz, hem de bugünkü siyasi çıkarlarımızdır. Azerbaycan - Türkiye ilişkileri çok 
hızla gelişmekte ve biz bundan dolayı çok mutluyuz", demiştir. Aynı toplantıda konuşan Başbakan Erdoğan ise Dağlık Karabağ sorununa değinerek şunları kaydetmiştir (Ahmedov, 2019);

"Dağllk Karabağ konusundaki tutumumuz, düşüncemiz, mücadelemiz birdir. Azerbaycan için Dağllk Karabă̆ konusu nasıl bir kanayan yara ise, bizim için de aynı kanayan yaradır. Bunun dışında farklı bir düşünce bizde olamaz. Bu meseleyi de sonuna kadar takip ediyoruz. Bundan sonra da takip etmeye devam edeceğiz."

16 Haziran 2012`de iki devlet arasında imzalanan "Trans Anadolu Doğalgaz Hattı Projesi (TANAP)" Antlaşması Azerbaycan`` Türkiye için önemli bir enerji partnerine dönüştürmüştür. Ayrıca Türkiye`yi Azerbaycan gazının Avrupa'ya ihracatı için önemli bir geçiş güzergâhına dönüştürmüş̧ür. 17 Mart 2015 tarihinde Türkiye`nin Kars ilinin Selim ilçesinde Azerbaycan Cumhurbaşkanı Aliyev, Türkiye Cumhurbaşkanı Erdoğan ve Gürcistan Devlet Başkanı Giorgi Margvelaşvili`nin katılımı ile TANAP`ın temel atma töreni düzenlenmiştir.

2013 yılının Şubat ayında Türkiye ile Azerbaycan arasında yeni bir enerji koridorunun oluşturulması kararlaştırılmıştır. Bu kapsamda "Trans Adriatik Boru Hattı Projesi (TAP)"'nin gerçekleştirilmesi ile ilgili bir bağlı anlaşma imzalanmıştır (Socar Midstream, 2020). Projenin gerçekleşmesi ile Azerbaycan doğalgazının İtalya'ya ulaşması planlanmıştır. Bu amaçla Yunanistan, Arnavutluk ve İtalya arasında doğalgaz hattının güzergâhı ve yapımı ile ilgili bir bağlı anlaşma imzalanmıştır. Bu durum Azerbaycan ve Türkiye'yi Avrupa devletleri için güvenilir bir stratejik enerji ortağına dönüştürmüştür.

Azerbaycan - Türkiye stratejik ortaklığı Rusya nın da bölgedeki küresel enerji projelerine katılımı açısından önem taşımaktadır. 2014 yılında Rusya Devlet Başkanı Vladimir Putin tarafından "Türk Akını" adı verilen doğalgaz projesi önerilmiştir. Bu proje Rusya'nın enerji rezervlerinin (doğalgaz ve petrol) Türkiye üzerinden Avrupa'ya taşınmasını sağlayacak bir projedir. 19 Kasım 2018 tarihinde Türk Akımı`nın deniz kısmının yapımının tamamlanması nedeniyle tören düzenlenmiştir. Bu ise Azerbaycan`ın gelecek jeostratejik çıkarları bağlamında önemli bir gelişme sayılmaktadır. Çünkü bu ortaklık Rusya-Türkiye-Azerbaycan üçlüsünün yer aldığı yeni bir işbirliği sürecinin başlaması anlamına gelmektedir (Memmedov, 2020).

30 Kasım 2019`da TANAP doğalgaz boru hattının Avrupa doğalgaz hattı ile birleşen kısmının açılış töreni gerçekleşmiştir. Böylece "Şahdeniz-2" kuyusundan Türkiye'ye ve Avrupa'ya ulaşan bu önemli projede doğalgaz nakil işlemlerinin önemli kısmı tamamlanmış ve 2020 yılında kemer faaliyete başlamıştır (Memmedov, 2020). 2020 yılında TANAP hattının TAP hattına birleştirilmesi planlanmıştır.

2019 yılına ait veriler dikkate alındığında Azerbaycan - Türkiye işbirliğinin tüm alanları kapsadığı ve yükselen bir ivme ile ilerlediği görülmektedir. Bu verile göre Azerbaycan'da 4000 Türk işadamı ve şirketi bulunmaktadır. Türk işadamlarının Azerbaycan daki yatırımlarının hacmi 12,5 milyar Dolar’a ulaşmışıtır. Azerbaycan'dan Türkiye`ye sermaye yatırımının hacmi ise 15 milyar Dolar’ı aşmıştır (İktisadi Islahatların Tahlili ve İletişim Merkezi, 2020).

\section{3. İKINCI KARABAĞ SAVAŞI NIN OLASI ETKILLERI}

Birinci Karabă̆ Savaşından sonra Ermenistan'ın Karabağ üzerindeki haksız işgali devam etmiş, hatta işgal altındaki toprak sınırını geniş̧etmek için ara ara tacizlerine devam etmiştir. 27 Eylül 2020`de Ermenistanın bu kapsamda yaptığı yeni bir saldırıya Azerbaycan ordusu tarafından karşılık verilmiş ve 27 yıldır işgal altındaki toprakların (ülkenin \%20'si) geri alınması amacıyla karşı taarruza geçilmiştir. 44 gün devam eden savaş sırasında Azerbaycan ordusu hiçbir sivili hedef almadan, kontrollü ve üstün bir şekilde işgal altındaki topraklarının önemli bir kısmını geri almıştır. Dağlık Karabağ'ın dışında bulunan yedi rayon ile Dağlık Karabağ bölgesinde bulunan Şuşa şehrini ve bazı kasaba ile köyleri işgalden kurtarmayı başarmıştır. 10 Kasım da imzalanan üçlü bildiri ile Dağlık Karabağ'ın Ermenistan işgalinden arındırılması sağlanmıştır. Bildiriye göre Karabağ'ın geri kalan kısmı Rusya barış gücünün denetiminde en kısa sürede Ermeni askerlerinden arındırılacağı ve bölgenin tamamının kayıtsız şartsız Azerbaycan devletinin anayasal düzenine gireceği belirtilmektedir.

Azerbaycan savaştan zaferle ayrıldığı için barış koşullarını belirleyen taraf olmuştur. 44 günlük savaş sırasında Türkiye Cumhuriyeti sahip olduğu tüm politik, diplomatik ve askeri olanaklariyla en üst düzeyde Azerbaycan`` desteklemiş, uluslararası hukukun gereğinin yapılmasında Azerbaycan'1 hiçbir şekilde yalnız bırakmamıştır. Türkiye'nin Azerbaycan`a kayıtsız şartsız destek vermesi ve bu desteğini açıkça dile getirmesi, savaş sırasında 
Azerbaycan'ın zafer kazanmasını istemeyen güçlerin Ermenistan tarafindan savaşa katılmasını ve açık cephe almasını engellemiştir.

Savaş, 10 Kasım`da Ermenistan`ın ağır yenilgisi ile sona ermiştir. Azerbaycan, Ermenistan ve Rusya imzaladıkları üçlü bildiri ile savaşı sona erdirmişlerdir. Bildiri üç ülke arasında imzalanmış olmasına rağmen, söz konusu bildirinin hazırlanmasında Türkiye'nin de taraf olarak Azerbaycan yanında yer aldığ 1 düşünülmektedir. Savaşın sonu yaklaştıkça Türkiye’nin Dıș İşleri Bakanı, Savunma Bakanı ile üst düzey siyasi ve askeri yetkililerinin kısa aralıklarla defalarla Bakü`ye gelmeleri; Türkiye Cumhurbaşkanı Erdoğan`ın Rusya Devlet Başkanı Putin ile olan telefon konuşmaları ve tüm bunlardan sonra bu bildirinin açıklanması, söz konusu iddiayı desteklemektedir.

Bildiri, savaşın hukuki ve siyasi sonuçları ile savaş sonrası bölgenin geleceği açısında büyük önemi bulunmaktadır. Bildiri ile Azerbaycan`ın dört rayonunun (Cebrayıl, Füzuli, Zengilan ve Gubadlı) işgalden kurtarıldığı resmileştirilmiş̧ir. Ayrıca üç rayonunun (Ağdam, Kelbecer ve Laçin) da işgaline son verilmesinin takvimi de belirlemiştir. Dağlık Karabağ'a hiçbir özerklik verilmeyeceği bildiride açıkça yer almıştır. Daha önceki barış görüşmelerinde ise Azerbaycan Ermenistan'ın işgale son vermesi karşılığında Dağlık Karabağ'a en yüksek politik özerklik verebileceğini beyan ediyordu. Fakat buna yanaşmayan Ermenistan ’n savaşta ağır yenilgi alması, barış şartlarının Azerbaycan'ın belirlenemesine neden olmuştur. Karabağ ile ilgili en büyük kazanımlardan birisi hiç şüphesiz özerklik statüsünün yer almamasıdır. Böylelikle Azerbaycan'ın toprak parçası olan Karağab üzerindeki egemenliği sınırlandırılmamış ve çok daha etkin olacaktır. Bu durum sadece Karabă̆ özelinde Azerbaycan için değil, tüm bölge açısından da oldukça önemlidir.

Bildirinin beşinci maddesi Karabağ'da konuşlandırılacak barış güçlerinin görev çalışmalarını denetlemek için bir komuta-kontrol merkezinin bulunacağını öngörmektedir (Aliyev, 2020). Bildirinin imzalandığı günden itibaren Rusya ile Türkiye arasında söz konusu komuta-kontrol merkezinin oluşturulması ve bu kapsamda askeri - diplomatik yetkililerin görevlendirilmesi ile ilgili görüşmeler gerçekleşmiştir. Bu görüşmeler esnasında merkezin konumu, merkezde bulunacak Türk ve Rus askeri yetkililerinin sayısı, bu kişilerin yetkilerinin dağılımı gibi hususlar belirlenmeye çalışılmıştır. Komuta kontrol merkezi ve merkezin faaliyetleri ile ilgili gerçekleştirilen görüşmeler esnasında Türkiye ile Azerbaycan sürekli olarak istişarelerde bulunarak ortak çıkarları doğrultusunda en optimal kararların alınması için çaba harcamışlardır. Merkezde Türkiye`nin askeri yetkililerinin yer alacak olması, aslında Türk ordusunun Güney Kafkasya'da barış süreci kapsamında bulunacağı anlamına gelmektedir. Bu ise gelecekte Türkiye'nin askeri açıdan daha güclü şekilde bölgede bulunmasının ilk adımı sayılmaktadır. Türkiye`nin bu hamlesi Ermenistan`` endişelendirmekte, Rusya yı da Türkiye nin artan gücünü kabul etmek zorunda bırakmaktadır. En önemlisi ise bölgeye ilgi duyan İran, ABD ve Avrupa Birliği gibi oyuncuları da kaybettikleri etkinlikleri nedeniyle telaşlandırmaktadır.

İkinci Karabağ savaşında kazanılan zafer Azerbaycan -Türkiye ilişkilerinde yeni bir dönemi başlatmaktadır. Her iki tarafın da Güney Kafkasya'da jeostratejik işbirliğinin yeni aşamasında elde edecekleri faydalar bulunmaktadır. Bu faydalar;

1. Azerbaycan'ın Ermenistan işgali altında bulunan \%20'lik topraklarının kurtarılması, bu bölgelerin ülkenin ekonomik sistemine entegre edilmesi sürecini başlatacak ve bu süreç yeni yatırım olanakları oluşturacaktır. Bu yatırım ortamından ise en fazla Türk işadamlarının faydalanması beklenilmektedir.

2. Dağlık Karabağ sorununun sona ermesi Azerbaycan Cumhurbaşkanı Aliyev'in de ifade ettiği gibi, yeni işbiriği oluşması için temel oluşturacaktır. $\mathrm{Bu}$ ise yeni projeler, küresel ölçekli gelişim olanakları demektir. Azerbaycan`ın stratejik ortağı olarak Türkiye`nin de bu projelerde belirleyici konumda olacağı kuşkusuzdur.

3. Şayet Ermenistan kendi yayılmacı tutumundan vazgeçerse, bölgede oluşan yeni işbirliği olanaklarından yararlanması ve yeni projelere katılması mümkündür. Bu ise Güney Kafkasya da artık daha önemli stratejik perspektiflerin oluşmasına neden olacaktır. Bu gerçekleşirse, hem Türkiye, hem de Azerbaycan için faydalı yatırım projelerinin hayata geçirilmesi söz konusu olacaktır.

4. İkinci Karabağ Savaşı artık Türkiye 'nin Güney Kafkasya ’nın jeopolitik ortamının belirleyici aktörlerinden birisi olduğunu tekrar ortaya koymuştur. Bu gerçeklik bölgenin geleceği açısında büyük önem taşımaktadır. Öncelikle, Azerbaycan Güney Kafkasya'da güvenilir bir ortak kazanmıştır. İkincisi, Türkiyen`nin Kafkasya bölgesinde etkili siyasi oyuncuya dönüşmesi, 10 Kasım 2020`de imzalanmış bildirinin uygulanması için de büyük önem taşımaktadır. Üçüncüsü, Türkiye`nin Güney Kafkasya`daki siyasi gelişmelerde yer alması bölgede Rusya nın politik tekelini sona erdirecektir. Artık Rusya kendi koşullarını dayatan taraf değil, Güney Kafkasya da yaşanan politik, ekonomik gelişmelerde eşit ağırlıklı 
bir taraftardır. Bu yeni gerçeklik Rusya - Azerbaycan, Rusya - Türkiye ilişkileri açısından yeni bir sayfa açacaktır. Yani kısa vadede Rusya 'yı Türkiye'nin geleneksel rakibi/düşmanı gibi değil, bölgede ortak çıkarları ve bu çıkarlar doğrultusunda işbirliği içinde bulunan taraf olarak görülebilir.

5. İkinci Karabağ Savaşı, Güney Kafkasya da mevcut olan diğer etnik sorunların çözümü için de önemli tecrübe oluşturmuştur. Sorunun bu yolla çözüme kavuşması bölgede sadece Azerbaycan`ın değil, Türkiye`nin de nüfuzunun artmasina neden olacaktır.

6. İkinci Karabağ Savaşı sırasında imzalanmış ortak bildiride Azerbaycan ile Nahçivan arasında Ermenistan topraklarından geçmek koşuluyla yeni ulaşım koridorunun açılması öngörülmüştür. $\mathrm{Bu}$ ise sadece Nahçivan`ın Azerbaycan`ın diğer bölgeleri ile bağlantısını sağlaması açısından değil, aynı zamanda Türkiye'nin de bölgedeki ekonomik gelişmelerde daha aktif yer alması açısından büyük önem taşımaktadır. Bunun gerçekleşmesi ilk başta Ermenistan için zararlı gözükse de esasen gelecekte bu ülkenin de Türkiye ve Azerbaycan ile ilişkilerini geliştirmesine katkı sağlayacaktır.

7. Ermenistan, Azerbaycan ile girdiği mücadelede sürekli olarak sivil halkı da hedef almıştır. Bunun en temel nedeni, Azerbaycan halkının kendi devletine olan güvenini zayıflatmaktır (İnaç, 2020:43). Ayrıca işgal ettiği yerlerdeki bölge (Azerbaycan) halkını yok etmek ya da zorunlu göçe sevkederek bu bölgeleri bir ermeni yurdu haline getirme amacı gütmüştür. Ancak yaşanan bu olaylar Azerbaycan halkında hiçbir güvensizliğin oluşmasına neden olmamış, aksine devletlerine olan güveni arttırmıştır. Ayrıca Azerbaycan devleti ve halkı bir bütün olarak Ermenistan devleti ve halkının bu soykırım kalkışmasına karşılık vermeyerek (sivil halka savaş) dünya kamuoyu nezdindeki haklılık ve saygınlıklarını arttırmışlardır.

\section{SONUÇ}

Azerbaycan bağımsızlı̆̆ını elde etmesinin üzerinden çok uzun bir zaman geçmemiş olmasına rağmen, bölgenin en önemli devletlerinden birisi haline gelmiştir. Bu durumun ortaya çıkmasında daha önce de belirtildiği üzere tarihsel kökeninin ve sahip olduğu gelişme yanlısı liderlerinin önemli bir etkisi vardır. Bu bağlamda ekonomik, sosyal, siyasal ve kültürel gelişmesinin meyvelerini kısa sürede toplamış olduğu görülmektedir. Çalışmada ele alınan 27 Eylül 2020 tarihi hem Azerbaycan, hem Güney Kafkasya, hem de Azerbaycan - Türkiye ilişkilerinin geleceği açısından son derece önemli bir dönüm noktasıdır. Bu tarih sadece Kafkasya bölgesi için değil, Türkiye'nin Orta Asya bağlantısını kesintisiz hale getirmesi açısında da büyük bir önem taşımaktadır. Hatta daha genel bir bakış açısıyla, yaşanan bu süreç, Türk Dünyası için çok daha büyük ve kapsamlı bir işbirliğinin sağlanmasına öncülük edecektir.

10 Kasım 2020 tarihinde Ermenistan`ın yenilgiyi kabul etmesi ve Rusya ’nın da katılımı ile imzalanan teslim aktından sonra bölgenin geleceği yeniden şekillenecektir. İkinci Karabağ Savaşı sonrası Güney Kafkasya da başlayan yeni dönemin en büyük kazananı kuşku yok ki, Azerbaycan ve Türkiye devletleridir. Esasen sağlanan bu barışta orta ve uzun vadede hiç kimse savaşın kaybedeni olmamıştır. Savaşı kaybeden ve teslim mütarekesi imzalamak zorunda kalan Ermenistan bile, yeni süreci doğru değerlendirirse ve Azerbaycan - Türkiye ile ilişkilerini normalleştirme yoluna giderse, savaşın kazananları arasında yer alabilecektir. Çünkü içinde bulunduğu ekonomik çöküntü, siyasi ve ekonomik açıdan mevcut olan dişa bağımlılığı, düşük düzeydeki bağımsızlığı, kötü komşuluk ilişkileri ve tüm bunlardan kaynaklı gelişemeyen ekonomisi her geçen gün Ermenistan'1 içinde yer aldığı bataklığa biraz daha gömülmesine neden olmaktadır. Yeni iyi ilişkiler mevcut olumsuz durumun azalmasına, hatta gerçekleştirilecek bölgesel işbirlikleri ile çok daha olumlu ve kalkındırıcı hale getirecektir. Ermenistan'ın bu konuda kendine örnek alabileceği bir ülke mevcuttur. Şüphesiz bu devlet Gürcistan'dır.

Gürcistan hem Türkiye, hem de Azerbaycan ile olan ilişkilerine her zaman büyük bir önem vermiştir. Bu tutumu nedeniyle de mevcut ilişkilerden yarar sağlayan bölge ülkesi olmuştur. Ermenistan da Gürcistan'ın izlediği yolu izlemeli ve kendi halkının refahını ve geleceğini düşünerek hiçbir temeli olmayan ilüzyonlarından vazgeçmelidir. Bu bağlamda sağında ve solunda yer alan iki güclü Türk devleti ile ilişkilerini dostane ilişkiler çerçevesinde kurmaya ve geliştirmeye çalışmalıdır. Fakat tarihten ders çıkarmaz ve komşularına karşı irredantist politikalar izlemeye devam ederse, emperyalist güçlerin elindeki bir maşa aracı olmaya devam edecektir. Bu nedenle de kendi geleceği yerine başka devletlerin çıkarları için kullanılan ve başta ekonomik - askeri olmak üzere kayıplar vermeye devam eden bir ülke konumunda kalacaktır. En önemlisi de yanlış tutum ve icraatları nedeni ile bu gün yaşadığı hezimeti yeniden yaşamaya mahkûm olacaktır.

Savaştan zaferle ayrılan Azerbaycan ve bu savaşta onu hiçbir zaman yalnız bırakmayan Türkiye ise her zaman olduğu gibi bundan sonra da kendi halklarının ve bölge halklarının refahı adına oluşan yeni jeopolitik ve 
jeoekonomik durumdan en çok fayda sağlayacak ülkeler olacaklar. Bu iki ülkenin işbirliği ile gerçekleşen tüm projelerden, önceki projelerde olduğu gibi bölge halkları da kazançlı çıkacaktır.

\section{KAYNAKÇA}

AHMEDOV, Elçin (2019), "Azerbaycan - Türkiye Strateji Tarafdaşll̆̆̆ Yeni ve Dinamik İnkişaf Merhelesinde", Azerbaycanda Atatürk Merkezi, https://ataturk.az/2019/04/04/azərbaycan-turkiyə-strateji-tərəfdasligiyeni-və-dinamik-inkisaf-mərhələsində/ (Erişim Tarihi: 29.11.2020).

ALIYEV, İlham (2020), “Azerbaycan Respublikasının Prezidenti, Ermenistan Respublikasının Baş Naziri ve Rusiya Federasiyasının Prezidentinin Beyanatı", Azerbaycan Cumhuriyeti Cumhurbaşkanlığı Kurumsal Web Sitesi, 10.11.2020, https://president.az/articles/45924 (Erişim Tarihi: 30.11.2020).

ASLANLI, Araz (2020), "10. Yllında Azerbaycan - Türkiye Stratejik Ortaklık Anlaşması ve Ortak Askeri Tatbikatlar", Anadolu Ajansı, 10.08.2020, https://www.aa.com.tr/tr/analiz/10-yilinda-azerbaycanturkiye-stratejik-ortaklik-anlasmasi-ve-ortak-askeri-tatbikatlar/1937068 (Erişim Tarihi: 28.11.2020).

AZERBAYCAN CUMHURIYETI CUMHURBAŞKANLIĞI (2010), “Azerbaycan ve Türkiye arasinda strateji emekdaşlıq şurasinın qurulması haqqinda beyanname imzalanmışdır", Azerbaycan Cumhuriyeti Cumhurbaşkanlığı Kurumsal Web Sayfası, 15 Eylül 2010, https://president.az/articles/721?locale=az (Erişim Tarihi: 15.09.2020).

ÇELIKSOY, Emine (2020), “Azerbaycan'da Bakanlar Kurulu ve İdare”, Kabine Bağlamında Karşılaştırmalı Ülke İncelemeleri (Ed. Metin Özkaral, Yasin Taşpınar), Nobel Akademik Yayıncılık, Konya, ss.63-78.

HASANOV, Ali (2005), Müasir Beynelxalq Münasibetler ve Azerbaycanın Xarici Siyaseti, Azerbaycan Yayınları, Bakü.

İKTISADİ ISLAHATLARIN TAHLILİ VE İLETIȘIM MERKEZI (2020), “Türkiye-Azerbaycan Xarici Ticaret Dövriyyesi Süratle Böyüyecek", İktisadi Islahatların Tahlili ve İletişim Merkezi Kurumsal Web Sayfası, https://www.iqtisadiislahat.org/.../nicat_hacizade_turkiye_azerbaycan_xarici_ ticaret_dovriyyesi_suretle_boyuyecek-909 (Erişim Tarihi: 02.12.2020).

İNAÇ, Hüsamettin (2020), "Yeni Dünya Düzeni Bağlamında Azerbaycan-Ermenistan Çatışması ve Kafkas Baharı”, M5 Ulusal Güvenlik, Savunma ve Strateji Dergisi, S.46(352), ss.34-44.

KOCAOĞLU, Mustafa (2015), “A Comparative Analysis within the Context of Central Government - Local Government Relationships in Local Governments at Turkey And Azerbaijan", International Journal of Business and Management Invention, S.4(4), ss.32-37.

MECEK, Mehmet (2018), “Azerbaycan’ın Devlet Yapısı ve Taşra Yönetiminde Merkez - Yerel İlişkileri”, Bitlis Eren Üniversitesi Sosyal Bilimler Enstitüsü Dergisi, S.7(1), ss.51-77.

MEMMEDOV, Vüsal (2020), "Enerji Sahesinde Yeni Emekdaşlıq Formatı Yaranır: Türkiye-RusiyaAzerbaycan", AzTv, 10.01.2020, http://www.aztv.az/az/news/4384/enerji-sahesinde-yeni-emekdasliqformati-yaranir-turkiye-rusiya-azerbaycan-marktehlilmark (Erişim Tarihi: 27.11.2020).

SAM - AZERBAYCAN RESPUBLIKASI PREZIDENTI YANINDA STRATEJI ARAŞDIRMALAR MERKEZI (2011), Azerbaycan -TürkiyeElaqeleri Son 20 İlde: Uğurlar ve İmkanlar, Azerbaycan Respublikası Prezidenti Yanında Strateji Araşdırmalar Merkezi Yayını, Bakü.

SOCAR MIDSTREAM (2020), "Trans-Adriatik Boru Kemeri: Qaz Ixrac Boru Kemeri", Socar Midstream Kurumsal Web Sayfası, http://www.socarmidstream.az/az/project/tap/\#cover (Erişim Tarihi: 29.11.2020).

TAN, Mehmet, ALIYEV, Pelin ve AYDIN, Abdullah (2013), "Sivil Toplum Kuruluşlart-Yerel Katılım Illişsisi: Azerbaycan Örneği”, Kuramdan Uygulamaya Yerel Yönetimler ve Kentsel Politikalar (Ed. Yakup Bulut, Veysel Eren, Sedat Karakaya, Abdullah Aydın), Pegem Akademi Yayınları, Ankara, ss.526-536.

Strateji Ortaklık ve Karşılıklı Yardım Anlaşması (16 Ağustos 2010). 